\title{
TANGGAPAN TENAGA KEPENDIDIKAN TERHADAP PENERAPAN FULL DAY SCHOOL DI SMA NEGERI 4 KOTA TERNATE
}

\author{
Nani I Rajaloa ${ }^{1}$, Rustam Hasim ${ }^{1}$, M. Akbar Hajuan ${ }^{2}$ \\ 1 Staf Pengajar Program Studi Pendidikan Pancasila dan Kewarganegaraan, FKIP-UNKHAIR \\ 2 Mahasiswa Program Studi Pendidikan Pancasila dan Kewarganegaraan, FKIP-UNKHAIR
}

Email: naniirajaloa@gmail.com

$\begin{array}{ll}\text { Diterima } & : 08-09-2019 \\ \text { Direvisi } & : 15-10-2019\end{array}$

Dipublikasi : 04-11-2019

\begin{abstract}
Abstrak. Penelitian ini dilatar belakangi oleh kondisi alam yang tidak mendukung seperti panasnya matahari, kemudian dengan fasilitas sarana prasarannya maka tenaga pendidik dan peserta didik selalu merasa bosan pada penerapan full day school di SMAN 4 Kota Ternate. Pemerintah daerah juga hanya menghimbau kepada sekolah-sekolah yang berada di Kota Ternate untuk menerapkan full day school akan tetapi belum ada kajian yang efektif untuk pelaksanaannya sehingga mengandung kontrovesi pada kalangan masyarakat mengenai hal tersebut. Penelitian ini bertujuan untuk mengkaji lebih dalam tentang tanggapn-tanggapan tenaga pendidik, tenaga kependidikan, peserta didik, dan orang tua tentang penerapan full day school di SMAN 4 Kota Ternate. Metode yang digunakan dalam penelitian ini adalah tipe penelitian kualitatif deskriptif. Penelitian kualitatif sebagai prosedur penelitian yang menghasilkan data deskriptif berupa kata-kata tertulis atau lisan dari orang-orang yang berperilaku yang dapat diamati. Tenaga Pendidik, Tenaga Kependidikan, Peserta didik, dan Orang Tua Wali, Subyek penelitian ini adalah menggunakan teknik "Propuse Sampling”. Sumber data yang digunakan dalam penelitian ini adalah data primer dan data sekunder. Teknik pengumpulan data adalah observasi, wawancara, dan studi dokumentasi. Hasil penelitian menunjukan pelaksanaan full day school di SMA N 4 Kota Ternate belum terlaksanakan dengan baik atau tidak eektif. Hal ini dibuktikan dengan kendala-kendalanya adalah prasarana, lingkungan sekolah serta aktivitas belajarnya yang terjadi terhadap penerpannya tidak efektif sehingga mempengeruhi potensi serta karakter peserta didik dan warga sekolah.
\end{abstract}

Kata Kunci: Evektivitas, penerapan, Full Day School.

\section{PENDAHULUAN}

Pendidikan adalah daya dan upaya manusia untuk berkembang lebih maju, baik berkembang jasmani dan rohaninya. Pendidikan sebagai proses memanusiakan manusia muda, yaitu pengangkatan manusia muda ke taraf yang berkualitas. Kehidupan adalah lingkaran proses kehidupan yang berawal dari ketiadaan menuju ke sesuatu yang ada dan kembali ke ketiadaan. Untuk memahami proses tersebut mutlak dibutuhkan pendidikan yang efektif. Tanpa pendidikan, manusia sulit memahami rahasia dibalik alam ini. Tanpa pendidikan, manusia sulit melakukan proses pematangan kualitas dirinya. Tanpa pendidikan, manusia sulit mengembangkan potensi, karier, dan masa depannya dengan baik. Tanpa pendidikan, manusia sulit memahami mana yang benar dan mana yang salah, mana yang baik dan mana yang buruk.

Dengan demikian, pendidikan berperan membantu manusia melakukan proses pembentukan kualitas jati diri. Pendidikan pada hakikatnya adalah proses menjadi, yakin menjadikan seseorang menjadi dirinya sendiri. Pendidikan dikembangkan melalui proses pembelajaran bermakna yang dilakukan dalam rangka pembentukan kepribadian unggul dan tercapainya titik kesempurnaan kualitas hidup. Pendidikan membantu manusia melakukan proses keseimbangan hidup dengan mempersempit jurang antara tuntutan kebutuhan belajar disatu sisi dengan peningkatan kualitas belajar peserta didik disisi lain.

Untuk membantu mengefektifkan dan meningkatkan kemampuan peserta didik tersebut, dibutuhkan tenaga pendidik, tenaga pendidikan dan sekolah yang efektif. Efektivitas berarti berusaha untuk dapat mencapai sasaran yang telah ditetapkan sesuai dengan kebutuhan yang diperlukan, sesuai pula dengan rencana, baik dalam penggunaan data, sarana, maupun waktunya atau berusaha melalui aktivitas tertentu 
baik secara fisik maupun non fisik untuk memperoleh hasil yang maksimal baik secara kuantitatif maupun kualitatif. Full day school merupakan sebuah sistem pembelajaran yang dilakukan dalam kegiatan belajar mengajar sehari penuh. Jadi, Full day school adalah sekolah sepanjang hari atau proses belajar mengajar yang dilakukan mulai dari pagi sampai sore hari. Sekolah dimulai sejak pagi hari sampai sore hari (07.00 s.d 16.00). Tujuan Full day school adalah untuk memberikan dasar yang kuat untuk mengembangkan dan meningkatkan kecerdasasan/inteligensi Quotient (IQ), Emotional Quotient (EQ), dan Spritual Quotient (SQ) dengan berbagai inovasi efektif dan aktual. Kurikulumnya didesain untuk menjangkau masing-masing bagian dari perkembangan ini yakni untuk mengembangkan kualitas penerapannya yang mencangkup integritas dan kondisi tiga ranah (kognitif, afektif, dan psikomotorik).

Salah satu peran full day school ini adalah agar potensi-potensi yang ada dalam diri peserta didik tadi dapat diketahui serta dikembangkan, jangka panjang dikemudian hari, agar peserta didik lahir dan tumbuh potensi yang berkualitas, selain itu agar anak mempunyai kegiatan di sekolah dibandingkan di rumah ketika orang tua mereka sedang bekerja. Full day school kebijakan yang bagus, tetapi belum mengenai sasaran hal ini disebabkan tidak lain dan tidak bukan karena belum siapnya sekolah untuk menerapkan full day school. Salah satu kendala adalah tenaga pendidik atau guru dan peserta didik yang belum siap, kelas belajar yang kurang nyaman dan fasilitas atau sarana dan prasaran yang tidak mendukung alat penunjang belajar lainnya seperti infocus, taman sekolah yang dijadikan tempat belajar, ini adalah kendala yang nyata dan jelas dalam mencapai full day school yang efektif dalam penerapannya.

Full day school atau disebut sekolah sehari penuh diterapkan pada sekolah-sekolah yang berada di Kota Ternate, salah satunya adalah SMA Negeri 4 Kota Ternate. Sebenarnya sistem full day school belum cocok diterapkan di Kota Ternate, dikarenakan kondisi alam yang tidak mendukung seperti panasnya matahari, kemudian fasilitas sekolahnya, atau sarana dan prasarana yang tidak mendukung, tenaga pendidik dan peserta didik juga merasa bosan ketika berada dalam kelas yang begitu lama mulai dari (07.00-16.00) WIT. Lahirnya full day school di SMA Negeri 4 Kota Ternate karena dihimbau oleh pemerintah daerah setempat yakni dinas pendidikan, namun himbauan tersebut belum ada kajian-kajian tertentu mengenai penerapan full day school di sekolah-sekolah yang berada di Kota Ternate, olehnya itu dampaknya adalah penerapannya tidak efektif. Nyatanya penerapan yang tidak efektif dikarenakan iklim sekolah yang tidak kondusif, sehingga tenaga pendidik dan peserta didik merasa bosan dalam proses pembelajarannya begitu juga orang tua peserta didik yang selalu merasa khawatir dengan anaknya yang berada di sekolah dengan waktu yang lama. Peserta didik juga sangat dipengaruhi oleh suasana sekolah, dengan demikian sekolah yang efektif harus membutuhkan tenaga kependidikan, yang efektif, tenaga pendidik yang efektif serta sarana dan prasaran dan orang tua yang mendukung. Efektifitas tenga pendidik atau kepemimpinan akan membawa kepada efektifitas sekolah begitu juga hal yang sama tenaga pendidik selaku pengajar atau guru sebagi penentu keberhasilan pendidikan di sekolah, guru dapat menyediakan fasilitas yang memungkinkan agar memudahkan kegiatan belajar anak didik seperti lingkungan belajar. Lingkungan yang tidak menyenangkan dapat mempengaruhi pelaksanaan sekolah sehari penuh, peserta didik merasa sungguh sangat membosankan karena lama di dalam kelas maupun diluar kelas. Dengan ketidak efektifan penerapan full day school mengakibatkan menurunnya semangat tenaga pendidik, tenaga kependidikan, orang tua, serta menurunnya semangat belajar peserta didik.

Berdasarkan latar belakang di atas, maka permasalahan yang di ajukan dalam penelitian ini adalah bagaimana tanggapan tenaga kependidikan terhadap penerapan full day school di SMAN 4 Kota Ternate?

\section{METODE PENELITIAN}

\section{Tipe Penelitian}

Adapun tipe penelitian yang digunakan adalah tipe kualitatif naturalistik. Menurut Ridwan, M (2004:51), tujuan penelitian kualitatif naturalistik adalah untuk mengetahui aktualitas, realitas, sosial 
dan presepsi manusia melalui pengakuan mereka yang tidak dapat diungkap melalui penonjolan pengukuran formal atau pertanyaan yang telah dipersiapkan terlebih dahulu. Lokasi penelitian ini telah dilaksanakan di SMA Negeri 4 Kota Ternate. Penelitian ini dilaksanakan selama bulan Januari hingga Februari 2019.

Dalam penelitian ini peneliti menentukan subyek dengan menggunakan "purposive sampling", yakni peneliti berusaha mendapatkan informasi dari data melalui orang-orang yang dinilai dan memiliki kemampuan untuk memberikan informasi yang akurat dan jelas, yang relevansi dengan masalah yang diteliti (Nurul Z, 2006:43). Dengan demikian, subyek dalam penelitian ini terdiri dari kepala sekolah, Guru bidang studi, kurikulum, dan peserta didik yang dianggap mampu dalam menjawab pertanyaanpertanyaan peneliti saat diwawancara di SMA Negeri 4 Kota Ternate.

\section{Teknik dan Prosedur Pengumpulan Data}

Untuk mendapatkan data yang sesuai dengan kebutuhan penelitian ini, maka peneliti menggunakan teknik penelitian, yakni:

a.) Observasi

Obsevasi merupakan salah satu alat pengumpul data yang menggunakan indera penglihatan sebagai media utamanya (Sukardi, 2013:79) dalam penelitian kualitatif observasi merupakan alat pengumpul data yang utama. Teknik observasi (pengamatan) ini merupakan teknik penelitian yang dilakukan oleh peneliti secara menyeluruh terhadap objek atau sasaran yang berkaitan dengan penelitian yaitu di SMA Negeri 4 kota ternate. dalam penelitian ini penulis turun langsung ke lapangan, yaitu tempat penelitian yang menjadi bagian dari objek untuk mengumpulkan data penelitian.

b.) Wawancara

Teknik wawancara terutama dilakukan dalam penelitian ini melalui wawancara tidak terstrukturdan mendalam. Ini dilakukan untuk memeperoleh data, tidak saja yang diketahui atau disadarioleh informan tetapi juga bersifat information. Pation (1990:280) dalam Syahril (2011:77) menyatakan bahwa pertanyaan-pertanyaan yang diajukan penelitian kualitatif dapat mengikuti dua macam pilihan yakni (1) Wawancara percakapan informal (the informal confersation), ialah wawancara yang sepenuhnya didasarkan pada susunan pertanyaan spontan ketika interaksi berlangsung khususnya pada proses obsevasi partisipatif dilapangan; (2) Wawancara atau interview, yaitu tanya jawab langsung dengan pihak sekolah dalam hal ini kepala sekolah, guru bidang studi, kurikulum, dan peserta didik SMA Negeri 4 Kota Ternate yang bertujuan untuk memperoleh data peneliti.

c.) Dokumentasi

Dokumentasi merupakan catatan peristiwa yang sudah berlalu. Dokumen bisa berbentuk tulisan, gambar, atau karya-karya monumental dari seseorang. Dokumen merupakan pelengkap dari penggunaan observasi dan wawancara dalam penelitian kualitatif (Sugiyono, 2010:329).

\section{Teknik Analisis Data}

Data kualitatif menurut Ryan dan Bernard (2000) adalah semua informasi berupa tes, surat kabar, sitcom, email, cerita rakyat, sejarah, kehidupan yang berguna untuk membangun dan mengarahkan pada pengembangan pengertian yang mendalam atas dasar setting orang-orang yang diteliti. Teknik analisa data yang digunakan dalam penelitian ini adalah teknik analisis deskriptif kualitatif yaitu menjelaskan kejadian yang terjadi di lapangan sesuai pengamatan, yang menyangkut tentang evektivitas penerapan full day school dalam upaya peningkatan kualitas belajar peserta didik, SMA Negeri 4 Kota Ternate.

\section{A. HASIL DAN PEMBAHASAN}

\section{Tanggapan Tenaga Kependidikan Terhadap Penerapan Full Day School Di SMAN 4 Kota Ternate}

Berdasarkan hasil wawancara dengan kepala sekolah (inisial KC) tentang tanggapan tenaga kependidikan terhadap penerapan full day school di SMA Negeri 4 Kota Ternate peneliti menemukan 
bahwa penerapan full day school di SMAN 4 Kota TERNATE masih memiliki banyak kekurangan serta kendala-kendala yang menghambat pelaksanaan aktivitas proses belajar mengajarnya, seperi dilihat dari belum siapnya tenaga kependidikan untuk menerapkan full day school di SMAN 4 serta disertai fasilitas prasrana yang tidak mendukung, iklim sekolah juga yang panas membuat warga sekolah tidak mampu melaksanakan full day school di SMAN 4 Kota Ternate.

Berdasarkan data hasil wawancara dengan Tata Usaha (inisial AS), mengatakan bahwa dengan penerapan full day school di SMAN 4 Kota Ternate menjadi contoh bagi sekolah-sekolah yang lain, dalam penerapannya harus memberikan ruang yang efektif serta waktu yang banyak bagi peserta didik maupun tenaga pendidik, namun full day school masih banya kekurangannya jika diterapkan pada wilaya sekitar Kota Ternate karena panasnya matahari menjadi kondisi lingkungan sekitar tidak mendukung, berada kelamaan diruang kelas selalu membuat kita tidak betah dan cepat bosan dan lelah oleh karena itu prasarana menjadi indikator utama dalam pelaksanaan full day school di SMAN 4 Kota Ternate, kemudian kita selaku tata usaha tidak merasa keberatan karena sudah terbiasa dengan waktu yang lama diruangan untuk menyusun administtasi atau tanggung jawab ia selaku tata usaha namun yang dipikirkan dan diperhatikan adalah tenaga pendidik dan peserta didik yang mana ia sering merasa tidak betah dengan waktu yang lama dalam kelas disaat proses belajar mengajar berlangsung karena sambung menyambung jam pelajarannya, istirahat ketika pada jam istirahatnya saja.

Berdasarkan hasil wawancara dengan kepala dinas pendidikan (inisial ND) mengatakan bahwa penerapan full day school atau disebut sekolah sehari penuh ini dua tahun silam menjadi polemik diberbagai daerah secara nasional khususnya wilayah indonesia, dan pada tahun 20017 sekolah SMA Negeri 4 Kota Ternate adalah sekolah yang pertama kali menerapkan full day school, lebih khususnya di Kota Ternate, berselang kemudian pada awal tahun ajaran baru 2019 full day school sudah tidak diterapkan di SMA Negeri 4 Kota Ternate disebabkan, yang pertama tidak ada regulasi dari kemendikbud maupun perda yang jelas dan kuat, dalam mengatur sekolah sehari penuh tersebut, kemudian yang kedua disetiap sekolah tidak ada anggaran yang lebih untuk membiayai makan minum terhadap guru-guru, olehnya itu mereka tidak mampu bertahan jika berada disekolah dengan waktu yang lama dari pagi hari hingga soreh hari, adapun yuran komite tiap bulan tapi tidak cukup untuk memenuhi kebutuhan makan minum dengan jumlah guru yang banyak, sehingga sekolah sehari penuh tidak lagi dijalankan oleh pihak SMA Negeri 4 Kota Ternate.

\section{Tanggapan Tenaga Kependidikan Terhadap Penerapan Full Day School Di SMA Negeri 4 Kota Ternate}

Berdasarkan hasil penelitian dengan tenaga kependidiikan terhadap penerapan full day school di SMA Negeri 4 Kota Ternate. Kepala sekolah (inisial KC) mengatakan bahwa penerpan full day school sebenranya didaerah perkotaan namun disisilain daerah kota ternate sebagian masyarakat pekerjaan kelas menengah dan tidak mampu membiayai anaknya pa sekolah sehari penuh, kemudian kendala fasilitas, sekolah harus menunjang disertakan lingkungan yang menyenangkan dalam pelaksanaannya, yang menjadi keberatan dalam pelaksanaan full day school adalah yaitu malas, maka peserta didik belum dikembangkan pada pelaksanaan full day school di SMAN 4 Kota Ternate, kendalanya adalah lama didalam kelas selalu merasa bosan dan terbeban dengan demikian peserta didik tidak lagi terkontrol dalam proses belajar mnegajar, guru sering mengontrol hanya pada jam istrahat dan solat, makan saja selain dari itu guru sudah tidak lagi mengontrol sehingga peserta didik menjadi kewalahan dan berkeliaran dalam ruangan kelas.

Kepala Perpustakaan (inisial ID), dan Tata Usaha (inisial AD) mengatakan hal yang sama bahwa penerapan full day school di SMAN 4 Kota Ternate dilakukan pada awal tahun ajaran 2017, pada saat bersepakat mencoba melaksanakan full day school tanpa melihat kekurangan full day school dan hanya dijalankannya saja, kemudian berselang dua tahun kemudian ia merasa bahwa waktu yang menjadi agak berat untuk dilalui, misalkan waktu mulai sekolah dari pukul 07.15 sampai dengan 15.45 merupakan waktu yang lama dan menjadi keresahan bagi peserta didik dan juga guru yang mengajar. Hal ini sejalan 
dengan pendapat Hasan (2006:116), berpendapat bahwa program pembelajaran model full day school tidak terlepas dari kelemahan dan kekurangannya, misalkan pertama, full day school acapkali menimbulkan rasa bosan pada peserta didik. Ini menunjukkan bahwa sistem pembelajaran dengan pola full day school membutuhkan kesiapan baik fisik, psikologis, maupun intelektual yang bagus. Baginya bukan hanya kesiapan fisik namun sarana dan prasaran pun menjadi salah satu tolak ukur kelemahan pelaksanaan full day school. Jika sarana belajar lengkap maka potensi serta kreatifitas membaca peserta didik dapat dikembangkan hal ini sejalan dengan pendapat Prastowo $(2012,229)$ sarana dan prasarana perpustakaan merupakan komponen yang tidak dapat dipisahkan, karena keberadaan sarana dan prasarana sangat penting bagi perpustakaan dalam menunjang semua aktivitas yang berjalan diperpustakaan. Jika sarana tidak lengkap akan membuat peserta didik kewalahan.

Berdasarkan hasil wawancara dengan Kepala Cabang Dinas Pendidikan Tingkat 1 Kota Ternate dapat dianalisis bahwa pelaksanaan atau penerapan full day school di Kota Ternate merupakan bermula dengan adanya wacana-wacana di tingkat pemerintah pusat (kementrian pendidikan) yang saat itu dipegang oleh Bpk. Muhajir Effendy, dengan dikeluarkannya Permen Nomor 23 tahun 2017 tentang hari sekolah, dimana sekolah harus melaksanakan 5 hari kegiatannya sehari penuh namun pada tingkat daerah tidak ada regulasi yang mewajibkan sekolah untuk menerapkannya. Oleh karena itu, jika sekolah di Kota Ternate yang menjalankan full day school dan kemudian berhenti tidak menjalankan lagi berarti bahwa sekolah tersebut tidak mampu karena dilihat dari kendala-kendala adalah bentuk kelemahan daripada penerapan sekolah sehari penuh tersebut. Tenaga kependidikan membutuhkan biaya makan minum yang lebih untuk kebutuhan dari pagi hingga sore hari. Hal ini menunjukkan kekurangan sekolah yang tidak sanggup membiayai tenaga kependidikan sehingga tidak dilaksanakannya program tersebut.

Penulis mengidentifikasi dengan wawancara dokumentasi dapat dianalisis bahwa waktu belajar yang lama walaupun belum terlalu efektif karena tidak didukung oleh fasilitas yang memadai, namun sekolah tetap menjalakannya dan berusaha berikan yang terbaik dalam pelaksanaannya. Hal ini sejalan dengan pendapat Aam Komariyah Cepi Triatna (2004), mengatakan bahwa efektivitas adalah ukuran yang menyatakan sejauh mana sasaran/ tujuan (kuantitas, kualitas, dan waktu) yang telah dicapai. Hal ini menunjukan bahwa penerapan full day school di SMA N 4 Kota Ternate dikatakan belum efektif. Yang menjadi kendala utama dan harus diperhatikan adalah sarana dan prasarana seperti sarana air menjadi ukuran bagi sekolah yang menerapkan program full day school.

\section{KESIMPULAN}

Penerapan full day school di SMA N 4 Kota Ternate sudah dilaksanakan namun tidak efektif dikarenakan full day school adalah sekolah yang diterapkan di wilayah perkotaan dan tidak mempunyai anggaran yang lebih serta fasilitas sarana tidak lengkap. Ada beberapa kendalakendala yang menghambat berjalannya pelaksanaan full day school diantaranya adalah sarana dan prasarana, yakni buku-buku diperpustakaan yang belum lengkap serta fasilitas minimalnya ase tidak mendukung, lingkungan belajar tidak menyenangkan karena budaya malas yang selalu diutamakan, sering merasa terbeban dan panasnya iklim sekolah, dan disaat proses belajar mengajar berlangsung peserta didik sering tidak fokus.

\section{DAFTAR PUSTAKA}

Dedi Mulyasana, 2011.Pendidikan Bermutu dan berdaya saing. Banndung, Remaja Rosda karya Ghofar, Abdul.1999. Cara Dahsyat Merevolusi Kemampuan Otak. Yogyakarta:Golden Books.

Hasan Nor, 2006. Full Day School Model Alternatif Pembelajaran Bahasa Asing. Volume 1. Nomor 1 Kartono. 1982. Pemimpin dan Kepemimpinan. Jakarta: Rajawali

KBBI, 20016. Kamus Besar Bahasa Indonesia (KBBI). [online] Avilabe at: http;//kbbi.web.id/dekat [Diakses 21 Juni 2019] Made Pidarta. Landasan Kependidikan. Penerbit Rineka Cipta. Jakarta

Nasution. 1986. Peran Orang Tua dalam Meningkatkan Prestasi Belajar Anak. BPK Gunung Mulia. Jakarta.

Oktamiati, H. \& Putri (2013). Tingkat Stres Akademik Anak usia sekolah terhadap sistem full day school disekolah dasar kab.bogor.jurnal. FIK UI

Sugiyono. 2010. Metode Penelitian Kuantitatif, Kualitatif, R\&D. Bandung Alfabeta 
Nani I Rajaloa, Rustam Hasyim, dan M. Akbar Hajuan. 2019. Evektivitas, penerapan, Full Day School.

Syafrida Siregar Lis Yulianti, 2017. Full Day School sebagai Penguatan Pendidikan Karakter. Volume. 05, No 02 Taylor dan Bogdan, 1994. Bentuk Penelitian Kualitatif Teori Dalam Penelitian Kualitatif. Jakarta: Mizan Pustaka. Undang-Undang No. 20 Tahun 2003, Tentang Sistem Pendidikan Nasional Jakarta: Depdiknas, Dirjen Dikdasmen 